\title{
Effect of no tillage on the physico-chemical properties of soils of the El Koudia region, Rabat (Morocco)
} \author{
Mouloud El Moudane ${ }^{1}$ and Ahmed Ghanimi ${ }^{1}$. \\ 'University Mohammed V, Faculty of Sciences, Department of Chemistry, Materials Laboratory, Nanotechnology and Environment, Rabat-Morocco. \\ ${ }^{2}$ National Institute of Agronomic Research (INRA), PO Box 6356, Rabat-Morocco.
}

Hassnae Maher ${ }^{1,2 *}$, Rachid Moussadek ${ }^{2}$, Abdelmjid Zouahri ${ }^{2}$, Ahmed Douaik ${ }^{2}$, Houria Dakak ${ }^{2}$,

\begin{abstract}
In Morocco, agriculture is an important sector of the economy, accounting for 15 to $20 \%$ of Gross Domestic Product. However, it has faced several challenges: intensive tillage of land that has accelerated water erosion, seriously threatening water and soil potential, low plant cover density and misuse of traditional agricultural practices, causing a decrease in organic matter levels and destroying aggregate stability. Climate change is making water and soil management in agriculture more and more complicated. The major challenge for Moroccan agriculture is to increase agricultural production while preserving natural resources. The objective of our study is to evaluate the effect of no tillage (NT) on the physicochemical properties of soil in the El Koudia experimental station, Rabat, Morocco. The crop is durum wheat, Arrehane variety. Soil samples are pre-dried, ground and screened to $0.2 \mathrm{~mm}$ for organic matter $(\mathrm{OM})$ analysis and $2 \mathrm{~mm}$ for the remainder of the analyses. Plugs, canned, are then sintered, screened and dried for structural stability tests. The results show that no tillage (NT) favours the accumulation of surface $\mathrm{OM}$, particularly at the $0-5 \mathrm{~cm}$ horizon unlike conventional tillage (CT). The NT promotes structural stability, with a mean weight diameter $(\mathrm{MWD})=0.94 \mathrm{~mm}$ for the NT compared to $0.83 \mathrm{~mm}$ for the CT. These results show that soils ploughed in CT are more exposed to erosion degradation than soils not ploughed (NT). In addition, NT preserves soil moisture and promotes additional water retention of 5 to $10 \%$.

Keywords: Agriculture, Erosion, no tillage, Irrigation, Soil, Water.
\end{abstract}

\section{Introduction}

Conservation agriculture was initiated in Morocco in the early 1980s. In 1983, INRA began research on this technique. A wider dissemination of the no tillage system has been carried out by development institutions in collaboration with INRA and higher agricultural education institutions [1]. This agricultural system is increasingly required to combat water and wind erosion, the destruction of organic matter and soil structure [2], and to cope with low soil productivity, low yields, degradation of natural resources, and the decrease in the rate at which local production meets needs. No tillage (NT), which is an integral part of conservation agriculture, is a conservatory soil and crop management system, in which the seed is placed directly into the soil that is never tilled [3]. It is presented as a solution to overcome the challenges facing agriculture today, particularly those related to climate change, globalization and price fluctuations and high input costs $[4 ; 5 ; 6]$. The main objective of the NT system is to ensure sustainable production; the absence of tillage could contribute to the fight against global warming by reducing energy expenditure and therefore carbon emissions and storage capacity via organic matter in the soil [7], and increasing its structural stability after an adaptation period of a few years [8]. In addition, it increases crop productivity with less fertilizer and increases soil potential. Indeed, Mrabet et al. found that phosphorus, nitrogen and potassium levels improve in no tillage compared to conventional tillage [9]. In Morocco, research over the past 30 years has shown the need to use no-till farming systems to improve soil quality and stabilize longterm yields [5]. This article contributes to this research effort by focusing on the changes that have affected the properties of a soil undergoing an NT system for 2 years. The focus will be on physical properties (soil texture, bulk density, structural stability) and chemical properties (organic matter, electrical conductivity, cation exchange capacity, macroelements such as phosphorus, potassium,magnesium and calcium and trace elements such as zinc, iron, copper, manganese). 


\section{Materials and methods}

\subsection{Study site}

The study site (Figure 1) is located at the El Koudia experimental station of the Regional Centre for
Agronomic Research in Rabat on secondary road 208 (Sidi Yahia Zaërs - Sidi Bettache, Morocco) $5 \mathrm{~km}$ from Sidi Yahia Zaërs, in the Rabat-salé-Kénitra region with the following coordinates: X: 356325 m; Y: 355189 m; Z: 193m.

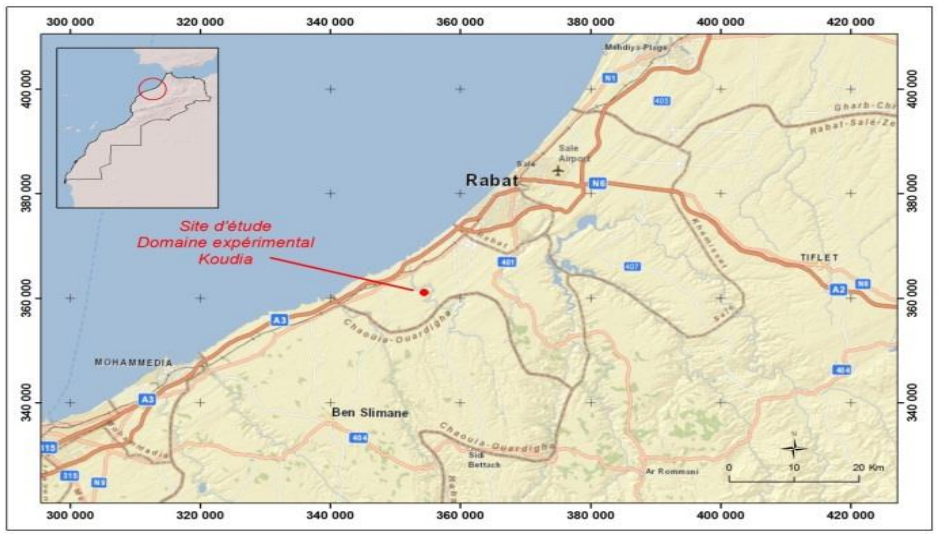

Figure 1. Presentation of the study site in the El Koudia experimental station.

The region is influenced by semi-arid and subhumid climates with hot and temperate winters. The average annual rainfall is about $460 \mathrm{~mm}$ while the average annual temperatures are around $18^{\circ} \mathrm{C}$.

The study site (Figure 2) is a 1.5 ha plot of land divided into two sub-plots that have been practicing

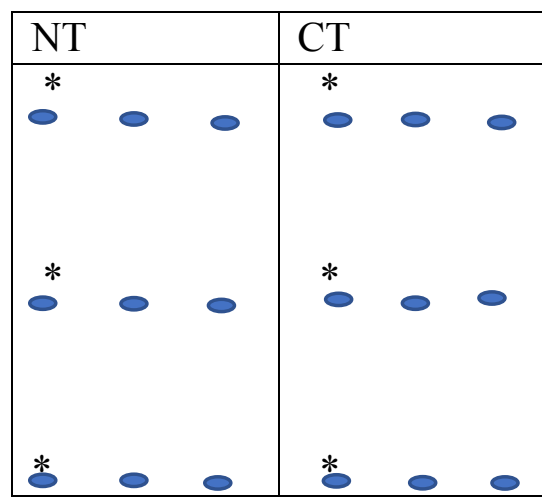

Figure 2: Test site plan with both systems (NT and CT) and sampling points.

\subsection{Sampling}

Soil sampling was carried out on April 2017, in both NT and CT plots, using a hand auger. Three replicates were made for each plot, with five depths per point $(0-5,5-10,10-15,15-20$, and $20-40 \mathrm{~cm})$. A sample in the form of superficial clods representing each plot was selected for the structural stability test. Three $0-10 \mathrm{~cm}$ horizon samples in each plot were placed in cylinders for the bulk density test. Samples were collected at the rate of 3 replicates per plot.

\subsection{Preparation of samples}

After collection, the soil samples were air-dried, hand-crushed and then screened to $2 \mathrm{~mm}$ to remove plant debris and stones larger than $2 \mathrm{~mm}$. An aliquot of the $0.2 \mathrm{~mm}$ sieve soil is kept for organic matter analysis.

\section{* Correspondingauthor:hassnaemaher@gmail.com}

two different agricultural management systems for two years: one has been practiced under no tillage (NT), while the other is under conventional tillage (CT), under grain-legume rotation. The previous crop is lentil/chickpea as legumes while as a second crop we have soft wheat (Arrehane variety) as cereals.

\subsection{Soil texture}

Soil texture [10], the mineral part of the soil, is a heterogeneous mixture of particles of very variable dimensions. A distinction is traditionally made between fine soil $(<2 \mathrm{~mm})$ and coarse elements $(>2$ $\mathrm{mm})$.

\subsection{Bulk density}

The bulk density corresponds to the dry weight of a volume of soil whose structure has not been disturbed. It is also the mass of a unit volume of soil dried at $105^{\circ} \mathrm{C}$. This volume includes both solids and pores. It is measured by the cylinder method [11].

\subsection{Structural stability}

Structural stability (SS) is a specific analysis of the physical properties of the soil. It is a good indicator 
of its sensitivity to soil sealingand water erosion. It is measured by tests applied in the laboratory according to the "LeBissonnais" method [12].

The results are expressed in $\mathrm{mm}$ as mean weight diameter (MWD):

MWD $=\left(\sum\right.$ (average diameter between two sieves $\times \%$ by weight of particles retained on the sieve) $) / 100$

\subsection{Electrical conductivity}

Electrical conductivity (EC) is an index of the contents of salts soluble in the soil solution, i.e. its degree of salinity [13].

\subsection{Organic matter}

Organic matter (OM) plays an essential role in maintaining soil quality, particularly in terms of water retention and the return of nutrients to plants (nitrogen, phosphorus, calcium, magnesium, etc.) [14]. The level of OM in the soil is determined by the method of Walkley-Black (1934). The carbon determination is carried out by wet process, it consists in cold oxidation of the carbon of the organic matter by a mixture of $1 \mathrm{~N}$ potassium dichromate $\left(\mathrm{K}_{2} \mathrm{Cr}_{2} \mathrm{O}_{7}\right)$ and sulphuric acid $\left(\mathrm{H}_{2} \mathrm{SO}_{4}\right)$ until the $\mathrm{CO}_{2}$ is released [15]. The $\% \mathrm{MO}$ is therefore obtained by multiplying the $\% \mathrm{C}$ determined by the Van Bemmlen factor:

$$
\% \mathrm{MO}=\% \mathrm{C} \times 1.724
$$

\subsection{Cationic exchange capacity}

Cation exchange capacity (CEC) is a measure of the size of the reservoir in nutrients that can easily pass through the soil solution. It represents the sum of the exchangeable acidity $\left(\mathrm{H}^{+}\right.$and $\mathrm{Al}^{3+}$ ions) and the exchangeable base cations $\left(\mathrm{Ca}^{2+}, \mathrm{Mg}^{2+}, \mathrm{K}^{+}, \mathrm{Na}^{+}\right.$, and $\mathrm{NH}_{4}^{+}$). Soil CEC must be measured at the $\mathrm{pH}$ of the soil solution to avoid changing the variable loads [16]. In conventional methods, CEC is measured either at $\mathrm{pH} 7$ (Metson method) [17] for weakly acidic to neutral soils or at $\mathrm{pH} 8.2$ (Bower method) [18] for alkaline soils, the latter have been investigated in our work.

\subsection{Macroelements}

\subsubsection{Phosphorus}

Phosphorus is a major element in the formation of nucleic acids, ATP and photosynthesis [19]. According to the Olsen method [20], the assimilable phosphorus is extracted by a sodium bicarbonate reagent $\left(\mathrm{HCO}_{3} \mathrm{Na}\right)$, buffered at $\mathrm{pH} 8.5$ with sodium hydroxide $(\mathrm{NaOH})$.

\subsubsection{Potassium}

Potassium, like phosphorus, is one of the major elements essential for plant growth and development. It plays a multiple role in the plant: ionic exchanges in the cell, activation of photosynthesis, protein synthesis [21]. The simplest and most commonly used method for the determination of potassium is the normal "K exchangeable with ammonium acetate" at $\mathrm{pH}=7[22]$, a simple and robust method [23].

\subsubsection{Calcium and magnesium}

Calcium and magnesium are adsorbed like other cations on the surface of mineral and organic colloids; they attach themselves to them by neutralizing negative charges. Calcium and magnesium usually form between 70 and $95 \%$ of the so-called exchangeable bases in soils [24]. The method based on extraction by neutral and normal ammonium acetate is the most widely used method for the determination of exchangeable calcium and magnesium. Three conditions are essential for theachievement of good complexometric dosages [25].

\subsection{Trace elements}

Trace elements play an essential role in the physiological cycle of plants. Several authors have summarized their role [26]:

Iron plays a major role in the synthesis of chlorophyll and proteins, the transport of oxygen, the metabolism of nitrates, and the enzymatic functions.

Manganese is bound to iron in its action on the formation of chlorophyll and in the metabolism of nitrates. It is involved in photosynthesis, enzymatic processes and protein metabolism.

Zinc participates in the metabolism of auxins, the synthesis of nucleic acids and proteins.

Copper is used in the composition of many oxidation enzymes; it is an enzyme activator. It participates in the synthesis of lignin. Thanks to this element, the plants keep a green and youthful appearance for a longer period of time, which is necessary throughout the growing season.

The DTPA (DiethyleneTriaminePentaAcetic Acid) extraction method developed by Lindsay and Norvell [27] has been adopted in many countries. This is probably the most widely used extraction technique to assess the assimilable $\mathrm{Zn}$ content of soils, as DTPA has proven to be a good extraction agent for several crops on very different soils. For this reason, we used this method in our work, which is based on the extraction of trace elements by DTPA, described by Mathieu and Pieltain [28].

\subsection{Statistical analysis}

Descriptive statistical analysis (mean, standard deviation, minimum, maximum and $\mathrm{CV}$ ) of the different characteristics was carried out for all the data and then for each type of sowing. Then, two conditions were verified: normality (using the 
Shapiro-Wilk test) and equality of variances (using the Levene test). If both conditions are verified, the analysis of variance (ANOVA) is used to compare the means of soil characteristics corresponding to the two types of seeding or the five depths. However, if either condition is not verified, a variable transformation must first be performed; otherwise, a non-parametric method such as the Mann-Whitney test must be used. The tests were applied at a probability level $\mathrm{p}=0.05$.

\section{Results and discussion}

\subsection{Soil texture}

According to Table 1, the granulometric analysis results of the soil samples from the two plots studied show that the soil studied has an identical texture of sandy silt.

Table 1. Soil texture for no tillage (NT) and conventional tillage (CN).

\begin{tabular}{|l|c|l|l|l|l|l|l|l|l|}
\hline & \multicolumn{5}{|c|}{$\%$ on dry fine soil } & \multicolumn{3}{c|}{$\%$ on mineral part } \\
\hline Type of tillage & C & FSi & GSi & FSa & GSa & limestone & C & Si & Sa \\
& $(\%)$ & $(\%)$ & $(\%)$ & $(\%)$ & $(\%)$ & $(\%)$ & $(\%)$ & $(\%)$ & $(\%)$ \\
\hline NT & 16,2 & 5,4 & 47,3 & 23,8 & 6,6 & 0,6 & 16,3 & 53,2 & 30,5 \\
\hline CT & 16,2 & 5,4 & 46,9 & 24 & 6,9 & 0,5 & 17,3 & 52,4 & 30,3 \\
\hline
\end{tabular}

C: Clay; FSi: Fine silt; GSi: Coarse silt; FSa: Fine sand; and GSa: Coarse sand.

\subsection{Bulk density}

Figure 2 shows a higher bulk density for no tillage $\left(1.53 \mathrm{~g} / \mathrm{cm}^{3}\right)$ than for conventional tillage (1.31 $\left.\mathrm{g} / \mathrm{cm}^{3}\right)$. This result is consistent with numerous studies conducted under various soil and climate conditions that conclude that the bulk density in no tillage increases in the first 5 to $10 \mathrm{~cm}$ of soil [30; 31]. The results obtained can be explained by the fact that in no tillage the soil is not disturbed and therefore remains relatively compact unlike conventional tillage.

The non-overturning of soil layers by ploughing or surface tillage techniques, especially no tillage techniques, and the presence of biopores therefore contributes to reducing the effects of these techniques on soil bulk density in the long term (beyond 10 years of adoption of these techniques) $[32 ; 33]$.

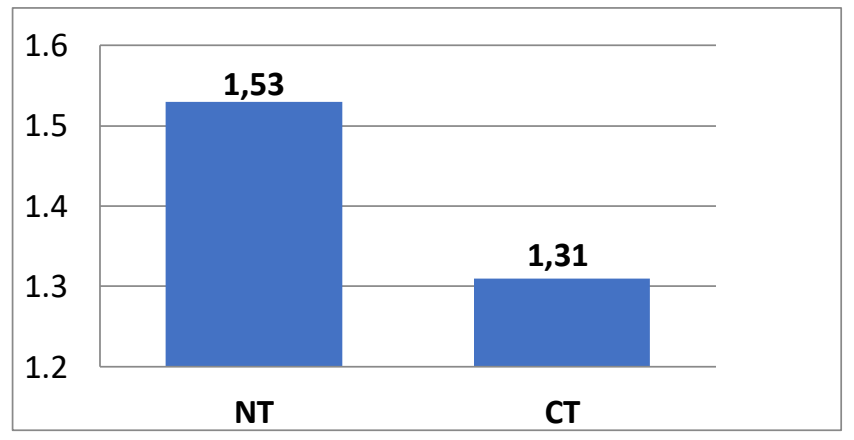

Figure 2. Bulkdensity $(\mathrm{g} / \mathrm{cm} 3)$ in the $0-10 \mathrm{~cm}$ depth for NT and CT.

\subsection{Structural stability}

The statistical analysis shows a significant difference between the three tests that correspond to specific conditions in terms of water condition, for both plots (Table 2). The results showed that the MDW values for NT and CT are very similar with a slight increase for NT. This result is due to the reason that the conservative technique applied to this soil is still new (2nd year of testing). The results show that the three tests are often correlated with each other, the water test is often the most destructive followed by mechanical disintegration, slow re-wetting, it allows to distinguish soils with very low stability because it is less harmful to the soils. The methodological framework of the Le Bissonnais method [12] takes into account three complementary treatments with different disintegration mechanisms, which provides a basic reference on the behaviour of soils under specific conditions in terms of water condition, humectant rate and applied energy. The results represent the average of the three tests (water, ethanol and rewetting) for structural stability at the level of the two plots and indicate a $\mathrm{MDW}=0.94 \mathrm{~mm}$ in NT greater than the CT value $(0.83 \mathrm{~mm})$. This soil is 
moderately stable according to the standards of "Le Bissonnais", which leads to frequent beating and variable runoff risks depending on climatic and topographical parameters.

Table 2. Results of the structural stability tests.

\begin{tabular}{|c|r|r|r|r|}
\hline Type of tillage & \multicolumn{1}{|c|}{ ET } & \multicolumn{1}{|c|}{ RH } & \multicolumn{1}{|c|}{ LH } & \multicolumn{2}{|c|}{ Mean } \\
\hline CT & 0,42 & 0,09 & 1,99 & 0,83 \\
\hline NT & 0,48 & 0,20 & 2,13 & 0,94 \\
\hline Mean & $0,45 \mathrm{~b}$ & $0,15 \mathrm{c}$ & $2,06 \mathrm{a}$ & 0,88 \\
\hline
\end{tabular}

ET: Mechanical disintegration (Ethanol test); RH: Rapid Humectation; LH: Slow re-Humectation. Means with different letters indicates significant differences at a probability level of 0.05 .

\subsection{Soil chemical properties}

The main descriptive statistics for $\mathrm{pH}$, depth, EC, OM, CEC, macroelements, exchangeable bases and trace elements are presented in Table 3.

Table 3. Descriptive statistical parameters of the different soil properties.

\begin{tabular}{|c|c|c|c|c|c|}
\hline Soil properties & Minimum & Maximum & Mean & $\begin{array}{l}\text { Standard } \\
\text { deviation }\end{array}$ & CV (\%) \\
\hline $\mathrm{pH}_{\text {water }}$ & 5,80 & 6,80 & 6,34 & 0,33 & 5,3 \\
\hline $\mathrm{pH}_{\mathrm{KCl}}$ & 5,30 & 6,20 & 5,86 & 0,25 & 4,3 \\
\hline $\mathrm{EC}(\mathrm{mS} / \mathrm{cm})$ & 0,04 & 0,13 & 0,07 & 0,03 & 45,2 \\
\hline OM (\%) & 1,15 & 1,59 & 1,37 & 0,15 & 10,7 \\
\hline CEC (meq/100g) & 4,58 & 12,86 & 8,47 & 2,28 & 26,9 \\
\hline $\mathrm{P}_{2} \mathrm{O}_{5}(\mathrm{ppm})$ & 51,48 & 123,39 & 72,35 & 21,51 & 29,7 \\
\hline $\mathrm{K}_{2} \mathrm{O}(\mathrm{ppm})$ & 197,00 & 990,00 & 296,30 & 244,82 & 82,6 \\
\hline $\mathrm{Ca}^{2+}(\mathrm{meq} / 100 \mathrm{~g})$ & 4,33 & 7,67 & 6,10 & 1,03 & 16,9 \\
\hline $\mathrm{Mg}^{2+}(\mathrm{meq} / 100 \mathrm{~g})$ & 1,33 & 5,67 & 3,23 & 1,64 & 50,8 \\
\hline $\mathrm{Zn}(\mathrm{ppm})$ & 0,03 & 0,35 & 0,10 & 0,09 & 93,1 \\
\hline $\mathrm{Fe}(\mathrm{ppm})$ & 0,67 & 1,53 & 0,95 & 0,25 & 26,7 \\
\hline $\mathrm{Mn}(\mathrm{ppm})$ & 0,59 & 15,05 & 3,98 & 5,43 & 136,4 \\
\hline $\mathrm{Cu}(\mathrm{ppm})$ & 0,01 & 0,07 & 0,04 & 0,02 & 39,0 \\
\hline
\end{tabular}

$\mathrm{pH}_{\mathrm{KCl}}, \mathrm{pH}_{\text {water }}, \mathrm{OM}$, and $\mathrm{Ca}^{2+}$ with a $\mathrm{CV}$ ranging

Table 3 shows that soil constituents are highly variable. However, this variability depends on the constituents. The most variable element is $\mathrm{Mn}$ with a coefficient of variation (CV) of $136.4 \%$, with an average value of 3.98 and values between 0.59 and $15.05 \mathrm{ppm}$. The second most variable component is Zn with a CV of $93.1 \%$ with an average of 0.099 and values ranging from 0.027 to $0.353 \mathrm{ppm}$, followed by $\mathrm{K}_{2} \mathrm{O}$ with a $\mathrm{CV}$ of $82.6 \%$, an average value of 296.3 and values between 197 and 990 ppm. Many other components have a similar variability of 26.7 to $50.8 \%$ : $\mathrm{Fe}, \mathrm{CEC}, \mathrm{P}_{2} \mathrm{O}_{5}, \mathrm{Cu}$, $\mathrm{EC}$, and $\mathrm{Mg}^{2+}$. The least variable components are

\section{*Correspondingauthor:hassnaemaher@gmail.com}

from 4.3 to $16.9 \%$.

\subsection{Comparison between NT and CT}

The Shapiro-Wilk normality test indicates that only the variables $\mathrm{pH}_{\text {water }}, \mathrm{pH}_{\mathrm{KCl}}, \mathrm{EC}, \mathrm{OM}, \mathrm{CEC}, \mathrm{Mg}^{2+}$, $\mathrm{Mn}$, and $\mathrm{Cu}$ follow a normal distribution. Among these variables, Levene's variance equality test indicates that the latter hypothesis is not verified for EC and $\mathrm{Mn}$. The logarithmic transformation of these two variables made equal variances. Therefore, ANOVA will be applied to the variables $\mathrm{pH}_{\text {water, }} \mathrm{pH}_{\mathrm{KCl}}, \mathrm{OM}, \mathrm{CEC}, \mathrm{Mg}^{2+}$, and $\mathrm{Cu}$ on their original scale whereas it will be applied to EC and 
Mn in their transformed (logarithmic) scale. For the other variables that do not follow a normal distribution $\left(\mathrm{P}_{2} \mathrm{O}_{5}, \mathrm{~K}_{2} \mathrm{O}, \mathrm{Ca}^{2+}, \mathrm{Zn}\right.$ and $\left.\mathrm{Fe}\right)$, the Mann-Withnay non-parametric test will be applied.

In addition to the formal Shapiro-Wilk normality test, a visual idea can be obtained by inspecting the boxplot of the variables. Thus, the graph in the upper left of Figure 3 shows that for $\mathrm{pH}_{\text {water, the two }}$ boxes corresponding to the two types of tillage are
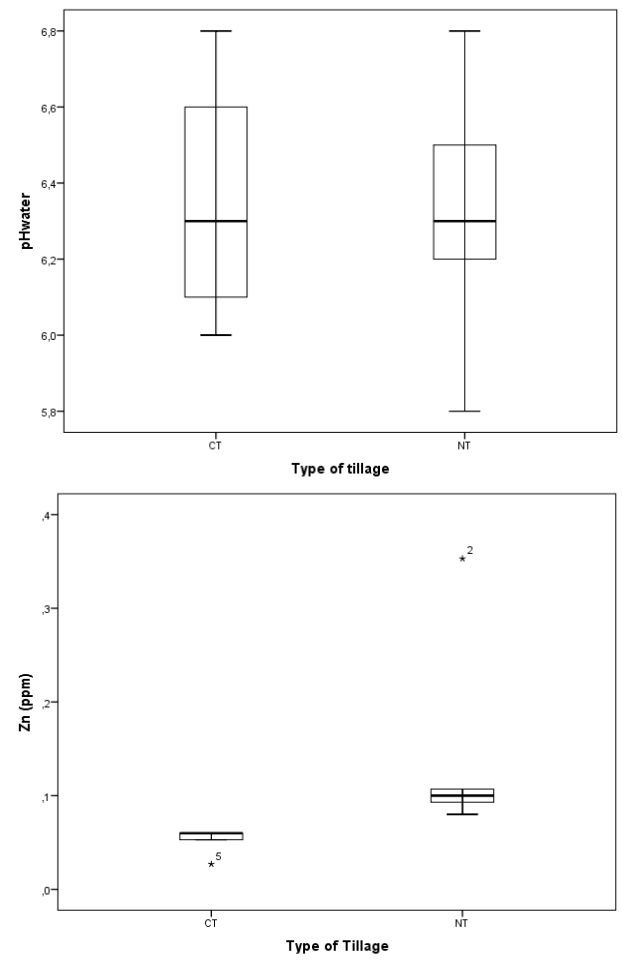

Figure 3. Boxplots of some soil properties: pHwater (top left), $\log (E C)$ (top right), Zn (bottom left) and Fe (bottom right).

\subsubsection{Variables with a normal distribution: ANOVA}

The results obtained from the analyses performed on our soil samples show a total dominance of weak acidic soil, according to the DIAEA/DRHA/SEEN 2008 standards. This is explained by the low limestone content in the soil which is characterized by a $\mathrm{pH}$ below 7 . Several studies [34] have found a highly significant relationship between limestone content and $\mathrm{pH}$. It can be seen that there is no variation in $\mathrm{pH}$ water either between the two NT and CT systems or as a function of depth.

According to the ANOVA, it can be observed that the average EC value differs significantly between the two types of tillage with a higher value in NT than in CT for all depths. This can be explained by the fact that in NT, fertilizers remain concentrated at the surface level while in CT the tillage distributes the fertilizers along the profile, therefore the concentration of salts is diluted and therefore the electrical conductivity here is lower. more or less symmetrical with the absence of atypical values. The upper right graph, corresponding to the log (EC) shows less symmetry with an atypical value. The distribution of these two variables is normal. On the other hand, the two bottom graphs ( $\mathrm{Zn}$ and $\mathrm{Fe}$ ) indicate the total absence of symmetry of the boxes as well as the presence of extreme values. These are indicators of the non-normal distribution of their distribution.

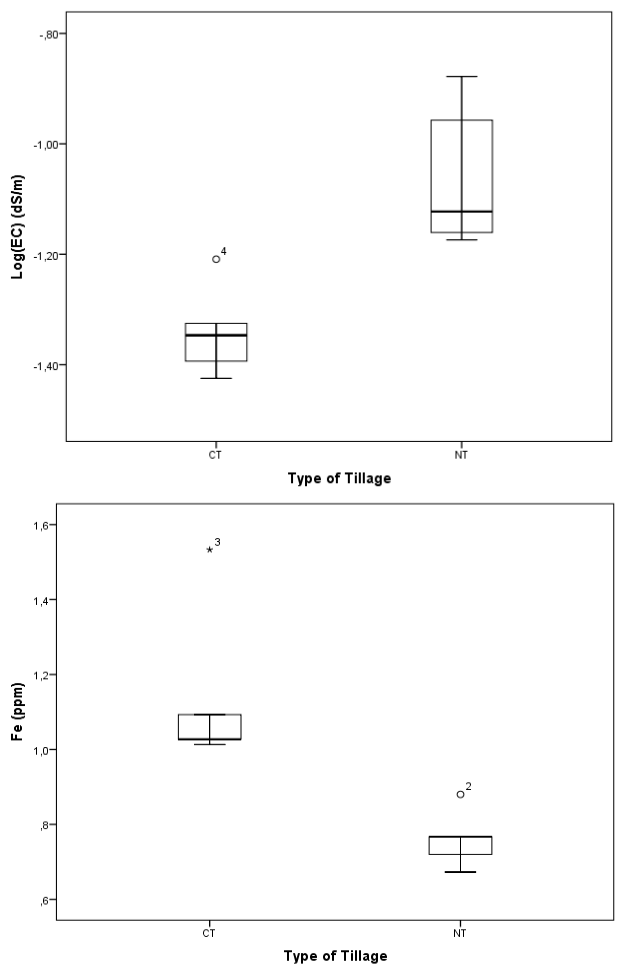

Analysis of the organic matter at the El Koudia site showed that the soil contains a moderately low content. By comparing organic matter contents between NT and CT, there is a higher valuein the former compared to the latter system at the $0-5 \mathrm{~cm}$ horizon and a lower value at the $10-40 \mathrm{~cm}$ horizon. This result is consistent with Balesdent's research on organic $\mathrm{C}$ stocks in conservation systems which are higher on surface than in ploughed systems [35], but few differences appear at depth [36]. Other studies have shown that organic carbon concentrations in conservation systems are generally higher in the first $10 \mathrm{~cm}$ of soil compared to ploughed soil and decrease sharply in the underlying horizons $[37 ; 38]$. Our results can be explained by the short period of application of the NT system in the trial (2 years). On the other hand, other authors show that tillage techniques have little effect on these stocks [39].

The CEC in the NT recorded a remarkably higher value compared to the $\mathrm{CT}$. The ability of a soil to store nutrients $\left(\mathrm{Ca}^{2+}, \mathrm{Mg}^{2+}, \mathrm{NH}_{4}^{+}, \mathrm{K}^{+}\right.$, etc. $)$and also $\mathrm{H}+$ ion depends on the clay and organic matter content of the soil. It has been measured in northern 
Brittany that about $50 \%$ of the CEC is directly carried by the soil OM [40]. The CEC of a soil varies very little over time. This explains the low CEC content of our studied soil with a sandy silty texture.

It can be seen that the NT system has an advantage over the CT system for magnesium, which has a high NT value in all 5 depths with a decreasing potential at depth.
The results obtained for $\mathrm{Cu}$ and $\mathrm{Mn}$ show that the value of these elements is important in NT than in CT at the surface $(0-10 \mathrm{~cm})$. This result can be explained by the fact that the colloidal properties of $\mathrm{OM}$, i.e. its character as an element binding substance and its chelating power, is likely to concentrate these contents at surface [41], with organic matter being more important under no tillage at the surface $[35 ; 42]$.

Table 4. ANOVA results for the comparison of means of normal variables.

\begin{tabular}{|c|c|c|c|c|c|c|c|c|}
\hline Type of tillage & $\mathbf{p H}_{\text {water }}$ & $\mathbf{p H}$ & $\mathbf{E C}$ & $\mathbf{O M}$ & $\mathbf{C E C}$ & $\mathbf{M g}^{2+}$ & $\mathbf{M n}$ & $\mathbf{C u}$ \\
\hline $\mathbf{N T}$ & 6,360 & 5,960 & $0,046 \mathrm{~b}$ & 1,418 & 7,194 & 1,933 & 1,532 & 0,047 \\
\hline $\mathbf{C T}$ & 6,320 & 5,760 & $0,091 \mathrm{a}$ & 1,320 & 9,754 & 4,533 & 6,424 & 0,040 \\
\hline Mean & 6,340 & 5,860 & 0,069 & 1,369 & 8,474 & 3,233 & 3,978 & 0,043 \\
\hline
\end{tabular}

Means with different letters indicate significant differences at a probability level of 0.05 .

\subsubsection{Non-normal distribution variables: non- parametric test}

The soil samples studied are characterized by a high concentration of assimilable phosphorus with an median of $67.5 \mathrm{ppm}$ for NT and $61.2 \mathrm{ppm}$ for $\mathrm{CT}$, which presents a soil rich in $\mathrm{P}_{2} \mathrm{O}_{5}$, according to interpretation standards, while it decreases with depth. The results obtained in the literature find that tillage techniques primarily influence how phosphorus is distributed in the soil. Whatever techniques are used, they have no significant effect on the phosphorus levels, which are generally very low, of the soil layers below the greatest working depth. Another study in the surface horizon showed that cropping operations that turn or mix the soil tend to homogenize phosphorus in the worked volume. On the other hand, those that do not generate a mixture of the layers worked on, lead to the introduction of a gradient of decreasing contents with depth [43], this is what we actually notice in our results.

The median potassium content under NT (206ppm) is lower than under CT (244ppm), these values show that our soil is rich in potassium by standards. It should be noted that at the $0-10 \mathrm{~cm}$ horizon, the
NT prevails over the CT, which is consistent with studies on the effect of no tillage on potassium [44], as well as the study that showed that in no tillage the amount of potassium can be reduced in depth [45].

The NT system has an advantage over the CT for calcium. According to the comparison of these results with the standards, the soil is moderately rich in minor elements.

According to the statistical analysis, it can be observed that the medians of zinc and iron differ significantly between the two types of tillage. $\mathrm{Zn}$ has an advantage in NT over CT, the opposite is true for iron. It has a low value for NT compared to CT. This can be explained by the existence of an antagonistic relationship between Fe and $\mathrm{Mn}$ : when one increases, the other decreases. In addition, in the case of compacted soils (high bulk density), iron tends to be less present than in more aerated soils. Taking into account the bulk density and the presence of iron and the $\mathrm{Fe} / \mathrm{Mn}$ antagonist relationship [46], Mn is more present in NT and much less in $\mathrm{CT}$ and vice versa for Fe. However, toxicity can only be determined by considering the $\mathrm{CEC}$ and the OM content.

Table 5. Results of the non-parametric test with medians for non-normal variables (Mann-Whitney test).

\begin{tabular}{|c|r|r|r|r|r|}
\hline Type of tillage & \multicolumn{1}{|c|}{$\mathbf{P}_{2} \mathbf{O}_{5}$} & \multicolumn{1}{c|}{$\mathbf{K}_{\mathbf{2}} \mathbf{O}$} & \multicolumn{1}{c|}{$\mathbf{C a}^{2+}$} & \multicolumn{1}{c|}{$\mathbf{Z n}$} & \multicolumn{1}{c|}{$\mathbf{F e}$} \\
\hline CT & 61,2 & 244 & 6 & $0,06 \mathrm{~b}$ & $1,027 \mathrm{a}$ \\
\hline NT & 67,5 & 206 & 6,7 & $0,10 \mathrm{a}$ & $0,767 \mathrm{~b}$ \\
\hline Mean & 64,4 & 225 & 6,3 & 0,08 & 0,897 \\
\hline
\end{tabular}

\section{* Correspondingauthor:hassnaemaher@gmail.com}


Medians with different letters indicate significant differences at a probability level of 0.05 .

\section{Conclusion}

This study allowed us to evaluate the effect of no tillage on the physico-chemical properties of the soil in the El Koudia experimental field, located 30 $\mathrm{km}$ from Rabat. The site under study consists of two plots, one for no tillage and the other for conventional tillage, the crop is a cereal, more precisely durum wheat, Arrehane variety. The results show that no tillage favours the accumulation of $\mathrm{OM}$ on the soil surface, especially at the $0-5 \mathrm{~cm}$ horizon, unlike conventional tillage. This high organic matter content explains the high adsorbency of nutrients in no-till soils, especially major elements and trace elements. This was confirmed by comparing our results with the literature searches. The NT also promotes bulk density and structural stability relative to the CT.

\section{References}

1. R., Mrabet, B.Vadon, and A. Ait Lhaj. Actes des resumes des premieres journees de rencontres sur le semis direct en Méditerranée. Centre Regional de la Recherche Agronomique, Settat, Maroc, 22-23: 31 (2001).

2. O. Zaghouane, Z. Abdellaoui and D. Houassine. Options Méditerranéennes, Série A, 69:183-187 (2006).

3. R. Mrabet. Nations commission économique pour l'Afrique. (Centre de développement pour l'Afrique du Nord (CDSR-AN). Tanger, Maroc, 4-9, (2001).

4. A. El Aissaoui, A. ElBrahli, O. El Gharras and N. El Hantaoui. Symposium international « agriculture durable enrégionméditerranéenne (AGDUMED) ", Rabat, Maroc 249-256, (2009).

5. R. Moussadek, R. Mrabet, and R. Dahan. Effet de l'agriculture de conservation sur la qualité des sols au Maroc. HTE 149/150: 25-28, (2011)

6. M. Laghrour, R. Moussadek, A. Zouahri, M. Mekkaoui, R. Dahan and M. El Mourid .J. Mater. Environ. Sci 6 (2) 391-396, (2015).

7. P.Y. Guedez. Rapport de stage en vue de l'obtention du diplôme d'études spécialisées en Sciences et Gestion de l'Environnement sous la direction de M.A. Reding (Monsanto) et A. Peeters (UCL), Université Catholique de Louvain, 97 pp, (2002).

8. J. Guerif. Edition INRA, Paris, p. 13-33, (1994).

9. R. Mrabet and R. Moussadek. Field Crops Research, 132: 84-94, (2012).

10. A. Richer de Forges, C. Feller, M. Jamagne and D. Arrouays. Etude et Gestion des Sols, 15: 2, p 97-111, (2008).

\footnotetext{
*Correspondingauthor:hassnaemaher@gmail.com
}

The increase in bulk density in no tillage compared to conventional tillage is unfortunately a handicap of no tillage, especially in the first years. This result can be explained by the recent use of the practice of no-till (NT) in the plot (2 years). The increase in the MWD at the NT level is a good sign of aggregate cohesion, which proves that no tillage contributes to improving soil structure. From these results, it can be concluded that ploughed soils are more exposed to erosion degradation than soils under NT with stable aggregates as shown in the structural stability test. However, it would be even better to extend this study, by carrying out several campaigns at different periods during the year to fully understand the beneficial effect of using appropriate conservation techniques for a sustainable and conservative agriculture of soils and their environment.

11. R. Blake andK. Hartage.Methods of soils analysis. Soil science, 1: 363-375, (1986).

12. Y. Le Bissonnais. European Journal of Soil Science, 47: 425-437, (1996).

13. J.P. Montori. Etude et Gestion des Sols 4: 279298, (1997).

14. M. Allaerts, W. Boon andJ. Feyen. Revue de l'agriculture, 35: 1673-1695, (1982).

15. A. Walkley and I. A. Black. Soil Science, 37: 29-38, (1934).

16.1. Charletand M. 1. Schlegel .Compte Rendu d'Académie d'Agriculture. 85: 7-24, (1999).

17. D. Baize . Guide des analyses enpédologie. $2 e$ édition, revue et augmentée, INRA Paris, (2000).

18. C. A. Bower, R. F. Reitemeier and M. Fireman. Soil Sci. 73: 251-261, (1952).

19. L. T. Benjamin, C. D. Barba J., M.C. Leo and Susan N. Talanta, 66: 294-306, (2005).

20. S.R. Olsen, C.V. Cote, F.S. Watanabe and L.A. Dean. U.S.D.A. Circular 939:8, (1954).

21. C. Graciaand S. D. Zimmermann .Frontiers in Plant Science, Montpellier, France, 5: 371, (2014).

22. C. Schvartz, J.Decroux and J-C. Muller. Guide de la fertilisation raisonnée :grandescultures et prairies. Paris: COMFIER Edition France agricole 137-138, (2005).

23. A. Mhiri. Atelier sur la gestion de la fertilité potassique, acquis et perspectives de la recherche, $\mathrm{p} 13$, (2002).

24. J. Boyer .Paris, OSTROM, 35: 173, (1978).

25. P. Pelloux, B. Dabin, G. Fillmann and P. Gomez .Méthodes de détermination des cations échangeables et de la capacitéd'échange dans les sols, Paris, (1971). 
26. A. Kabata-Pendias. CRC press LLC. p.430, (2001).

27. W. L. Lindsay and W. A. Norvell .Soil Science Society of America Journal, 42: 421-428, (1978).

28. J. C. Katyal and N. S. Randhawa. Organisation des Nations Unies pour l'alimentation et l'agriculture, page 12, (1986).

29. C. Mathieu and F.Pieltain. Editions Tec et Doc/Lavoisier, Paris, 408 p, (2003).

30. J. Lampurlanés and C. Cantero-Martínez .Agronomy Journal, 95: 526-536, (2003).

31.F. Basic, I. Kisic, M. Mesic, O. Nestroy and A.Butorac. Soil \& Tillage Research, 78: $197-$ 206, (2004).

32. E. Dinon and A. Gerstmans. Université de Liège, (2008).

33. A. K. FRANC-XAVIER. Université Félix Houphet-Boigny, UFR des sciences de la terre et des sols, (2016).

34. M.J.S. Floate and P.D. Enright .New Zealand Journal of agricultural Research. 34: 453-465, (1991).

35. K. D'Haene, J. Vandenbruwane, S. De Neve, D. Gabriels, J. Salomez and G. Hofman .European Journal of Agronomy 28: 449-460, (2008).
36. J. Balesdent, C. Chenu and M. Balabane .Soil \& Tillage Research. 53: 215-230, (2000).

37. M.M. Al-Kaisi and X. Yin.Journal of evironment quality 34: 437-445, (2005).

38. A. Gál, T.J. Vyn, E. Michéli, E.J. Kladivko and W.W. Mcfee .Soil and Tillage Research, 96: 42-51, (2007).

39. E.S. Keith, C.J. Baker, W. R. Ritchi, F. Ribeiro and al. CABI and FAO, London, p. 326, (2006).

40. B. Decoopman, D. Hanocq and D. Heddadj. Dossier pour le pôle agronomie-productions végétales des chambres d'agriculture de Bretagne, (2013).

41. M.Sillanpaa .Soils Bulletin17: 1-67, (1972).

42. H.J. Koch and N. Stockfisch. Soil and Tillage Research, 86: 73-83, (2006).

43. A. N. Sharpley.Journal of Environmental Quality, 32: 1375-1384, (2003).

44. J.H. Edwards, C.W. Wood, D.L. Thurlow and M.E. Soil Science Society of America Journal, 56: 1577-1582, (1992).

45. C. Pekrun, H.P. Kaul and W. Claupein .In: $E l$ Titi, A. (ed.), Soil tillage in agroecosystems, CRC Press, New-York (USA), pp. 83-113, (2003).

46. B. Estevez. Agriculture pêcherie et alimentaire au Québéc,

(2006). 